\title{
The current economic state of the tourism industry of Pavlodar region and the assessment of strategic investments in its development ${ }^{1}$
}

\author{
A.A. Titkov ${ }^{1}$, S.Zh. Ibraimova ${ }^{2}$, M.M. Begentayev ${ }^{1}$, S.K. Kunyazova ${ }^{1}$ \\ ${ }^{1}$ Toraighyrov University, ${ }^{2}$ Kazakh University of Technology and Business
}

\begin{abstract}
The article examines the current state and economic trends in the functioning of the tourism industry of Pavlodar region. The object of the research is the economy of the Pavlodar region. In the course of the study, attention is focused on the dynamics of the nominal and real contribution of the tourism industry to the regional economy, the territorial distribution of tourism services and their structure in the context of types, trends in employment and labor productivity in the industry, production capacity and the state of their fixed capital. When assessing the real contribution of the tourism industry to the development of the regional economy, the dynamics of demand for tourism services from individuals and legal entities was investigated. For the development of the tourism industry in the region, an integrated analytical assessment of strategic investments has been made. Implementation of the developed investment policy makes it possible to significantly increase the volume of tourism services in the region, to strengthen the trends in the industry's contribution to the economy. The results of the research can be used in the system of activities of regional, regional departments of tourism and sports in the Republic of Kazakhstan.

Key words: tourism industry; tourist services; market of tourist services; gross regional product; supply and demand; productive capacity; investments.
\end{abstract}

\section{Павлодар облысының туризм индустриясының қазіргі экономикалық жағдайы және оның дамуына стратегиялық инвестицияларды бағалау}

Түйін

Мақалада Павлодар облысының туризм индустриясының қазіргі жағдайы мен экономикалық тенденциялары қарастырылған.

Зерттеу нысаны - Павлодар облысының экономикасы.

Зерттеу пәні - туризм индустриясы және оның прогрессивті дамуына тартылатын стратегиялық инвестициялар. Зерттеу барысында Павлодар облысының экономикасына туристік индустрияның номиналды және нақты үлесінің динамикасына, туристік қызметтердің аумақтық бөлінуіне және олардың кеңейтілген түрлері, жұмыспен қамту тенденциясы жағдайындағы олардың құрылымына, туристік индустриядағы еңбек өнімділігі, туристік ұйымдардың өндірістік куаты және олардың негізгі капиталының жағдайына ерекше назар аударылады. Туризм индустриясының аймақтық экономиканың дамуына қосқан нақты үлесін бағалау кезінде жеке және заңды тұлғалардың туристік қызметтерге сұранысының динамикасы зерттелді. Өнірдегі туристік саланы дамыту үшін жалпы өнірлік өнімді, оның өсу қарқынын, туризмнің аймақ экономикасындағы үлесін, туристік қызметтер көлемінің серпінін, туристік ұйымдардың қор қайтаруын болжау негізінде стратегиялық инвестицияларды ірілендірілген-талдамалық бағалау орындалды. Туристік индустрияны дамытуға арналған стратегиялық инвестициялар басымдықтармен - негізгі қорлармен және адам ресурстарымен әртараптандырылады. Дамыған инвестициялық саясатты іске асыру аймақтағы туристік қызметтер көлемін едәуір арттыруға, туристік индустриядағы еңбек өнімділігін үш есеге арттыруға және туризм индустриясының Павлодар облысының экономикасына қосқан үлесінің оң тенденциясын күшейтуге мүмкіндік береді. Жүргізілген зерттеу тәжірибеге бағытталған сипатқа ие және қолданбалы маңыздылыққа ие. Зерттеу нәтижелерін Қазақстан Республикасындағы облыстық, өңірлік туризм және спорт басқармаларының қызмет жүйесінде қолдануға болады.

Түйін сөздер: туризм индустриясы; туристік қызметтер; туристік қызмет көрсету нарығы; жалпы аймақтық өнім; сұраныс пен ұсыныс; өндірістік қуат; инвестициялар.

\section{Современное экономическое состояние туристской отрасли Павлодарской области и оценка стратегических инвестиций в ее развитие}

\section{Аннотация}

В статье рассмотрены современное состояние и экономические тенденции функционирования туристской отрасли Павлодарской области. Объектом исследования выступает экономика Павлодарской области. Предметом исследования выступает туристская отрасль и стратегические инвестиции в ее поступательное развитие. В ходе исследования особое внимание акцентировано на динамике номинального и реального вклада туристкой отрасли в экономику Павлодарской области, территориальном распределении туристских услуг и их структуре в разрезе укрупненных видов, тенденциях занятости и производительности труда в туристской отрасли, производственных мощностях туристских организаций и состоянии их основного капитала.

1 The study was carried out as part of the implementation of the regional state budget funded research work «Concept for the development of year-round tourism in Pavlodar region until 2025».

In the research and writing of a scientific article, advisory support was provided by leading scientists of the Department of Economics of Toraighyrov University. 
Исследована динамика спроса на туристские услуги со стороны физических, юридических лиц с учетом оценки реального вклада туристской отрасли в развитие экономики региона. Для развития туристской отрасли региона выполнена укрупненно-аналитическая оценка стратегических инвестиций на основе прогнозирования валового регионального продукта, темпов его роста, удельного веса туризма в экономике региона, динамики объемов туристских услуг, фондоотдачи туристских организаций. Стратегические инвестиции в развитие туристской отрасли диверсифицированы по приоритетам - основной капитал и человеческие ресурсы. Реализация выработанной инвестиционной политики позволяет значительно увеличить объемы оказания туристских услуг в регионе, утроить производительность труда в туристской отрасли, усилить положительные тенденции вклада туристской отрасли в экономику Павлодарской области. Проведенное исследование имеет практикоориентированный характер и прикладную значимость. Результаты исследования могут быть использованы в системе деятельности областных, региональных управлений туризма и спорта в Республике Казахстан.

Ключевые слова: индустрия туризма; туристические услуги; рынок туристических услуг; валовой региональный продукт; спрос и предложение; производственная мощность; инвестиции.

\section{Introduction}

The tourism industry refers to the service sector with high added value, which is directly aimed at meeting the spiritual and moral needs of a person and society, allowing people to study the culture of different countries of the world and the development trends of civilization as a whole. In the context of the transition of the economy of many developed and developing countries of the world to scientific and technological progress based on the principles of «Industrialization 4.0 », the tourism industry does not stand aside. In the field of tourism services, innovative solutions are generated based on a number of tools, such as experience economy, innovative marketing, innovative management of tourism clusters, modern innovative systems for managing transport communications and passenger traffic. The Republic of Kazakhstan, as the center of Eurasia, has a significant tourist potential, which, if used correctly, can allow diversifying the country $\mathbf{s}$ economy, developing an export-oriented non-raw material sector. For the development of the tourism industry in the Republic of Kazakhstan, a target departmental State program «Development of the tourism industry of the Republic of Kazakhstan for 2019 - 2025» has been developed and adopted. All regions of the country should be involved to the maximum extent in the implementation of this program.

Pavlodar region, in which the Bayanaul National Park-Reserve is located, has a significant tourist potential in the Republic of Kazakhstan. Also, the region has ample opportunities for the development of sacred and spiritual, sports, rural, industrial tourism. The relevance of the development of the tourism industry in Pavlodar region requires an in-depth economic analysis of its state on the one hand and a comprehensive assessment of strategic investments in its development on the other hand.

\section{Literature review. Theoretical,} methodological and applied aspects of the development of regional tourism are widely covered by Kazakhstani scientists, scientists from near and far abroad. Kazakhstani scientist Uakbaev Sh.U., notes that the tourist region is a separate territory, within which various tourist resources are concentrated. Tourist regions in the framework of economic analysis are relevant to systematize into meso (micro) and macro regions. Tourist macro regions mean the tourist industry of the country as a whole. Systemic economic analysis and modeling of processes in the regional tourism industry are based on a retrospective analysis that covers a period from 5 to 15 years. This takes into account socioeconomic factors, features of the regional economy [1].

Research scientist Perelygina M. from Hong Kong Polytechnic University in the development of regional tourism focuses on the trends of inbound and outbound tourism, while introducing the concept of «cultural distance» [2].

Researchers from the Russian Federation, Novikova N.G., Lebedev K.A., Lebedeva O.E., note that the development of regional tourism involves the creation of special small and medium-sized tourist enterprises, while there is a multiplier effect due to the development of related industries economies: construction, trade, agriculture, transport, communications, culture and art. Regional investment support for the tourism industry is systemic and complex and involves:

- public investment;

- funds of foreign investors, including through the creation of joint tourism enterprises;

- consolidation of share capital and creation of large regional tourism corporations;

- bank lending and leasing security [3].

In the studies of scientists from far abroad, when considering the development of regional tourism, the emphasis is on the priorities of investment in the construction of tourist clusters. At the same time, along with monetary investments, the intellectual potential of research organizations, educational organizations, and tourist organizations is accumulating [4]. Also, the emphasis is on the correlation between the development of the tourism industry and the growth of the regional economy. At the same time, there should be a parity investment policy in both the development of urban and rural tourism [5]. 
Certain scientists-researchers, in the search for the optimal priorities of the investment policy for the development of the tourism industry, have established patterns that investments will be effective, provided that the income of the population grows and their location is closer to places of rest. These aspects are considered in scientific research of Portuguese scientists Cro S., Martins A.M. [6]. The role of investment in the tourism industry, focused on the quantitative growth of tourism services and the creation of new jobs, was considered by the scientist Ilie G. from Romania [7].

The direct dependence of investment in the tourism industry and gross value added is considered in a scientific study by scientists from Kazakhstan, Croatia, India, Indonesia [8, 9, 10, 11].

\section{Methodology}

The main research methods were: analytical and synthetic, statistical, calculation and analytical research methods. The hypothesis design method was also used. Within the framework of the analytical research method, all the constituent elements of the tourism industry of Pavlodar region were analyzed separately, such as: nominal and real volume of tourism services; the volume of tourist services in the context of the territories of the region; employment, wages and labor productivity in the tourism industry; dynamics of tourism industry organizations; condition of fixed capital and production facilities of the tourism industry. The analytical method made it possible to determine the problem points of the functioning of the tourism industry in the region. The analytical method was coupled with the statistical research method. Based on the analytical method, the hypothesis method was applied. Within the framework of the main hypothesis, it was determined that the tourism industry of the region needs investment: investment in infrastructure development (fixed capital) and investment in human resources. Based on the method of hypotheses, to achieve the resulting indicators, a synthetic research method was applied, within which the calculation and analytical method was also applied.

\section{Results and discussion}

The tourist industry and tourist services in Pavlodar region, despite a significant period of formation of market relations in the region, is at the stage of development. The functioning of the tourism industry is accompanied by insignificant economic cycles, and its nominal contribution to the development of the regional economy, for 2015 - 2019, varied from $0.55 \%$ to $0.3 \%$ (Table 1 , Figure 1).

Table 1 - Nominal dynamics of assessing the contribution of the tourism industry to GRP

\begin{tabular}{|l|c|c|c|c|c|}
\hline \multicolumn{1}{|c|}{ Index } & \multicolumn{5}{c|}{ Year } \\
\cline { 2 - 6 } & 2015 & 2016 & 2017 & 2018 & 2019 \\
\hline Gross regional product of Pavlodar region, a billion tenge & 1736,2 & 1975,5 & 2369,3 & 2746,7 & 2805,9 \\
\hline $\begin{array}{l}\text { Nominal tourism services (full range of services directly } \\
\text { and indirectly related to tourism), a billion tenge }\end{array}$ & 9,6 & 8,7 & 9,9 & 7,9 & 8,5 \\
\hline $\begin{array}{l}\text { The nominal contribution of the tourism industry to GRP, } \\
\%\end{array}$ & 0,55 & 0,44 & 0,42 & 0,29 & 0,30 \\
\hline \multicolumn{5}{|l|}{ Note - In accordance with sources [12,13] }
\end{tabular}

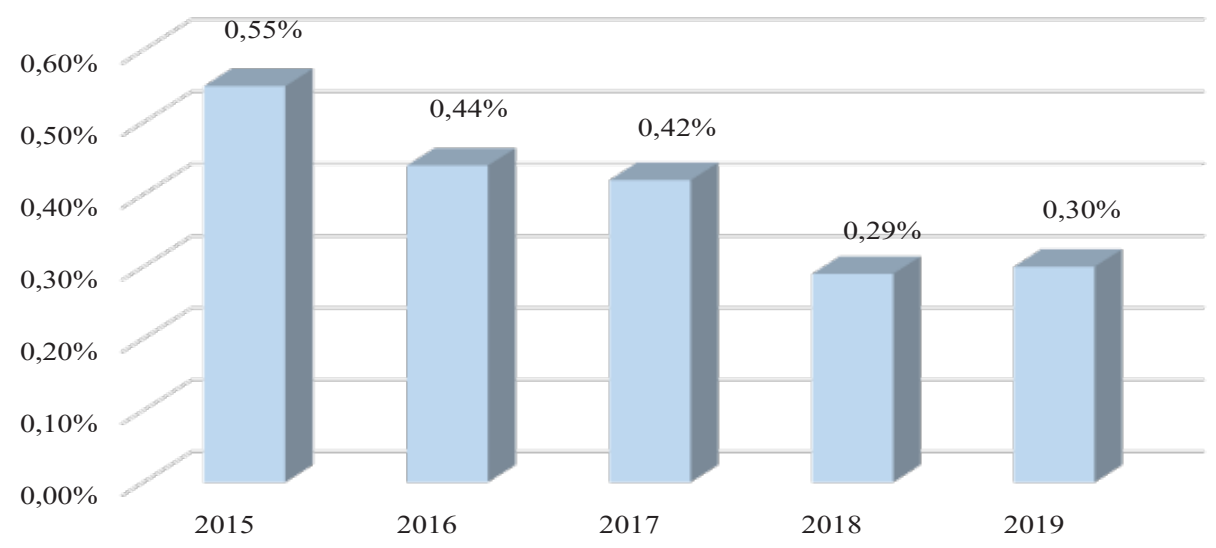

Note - In accordance with sources $[12,13]$

Figure 1 - Dynamics of the nominal contribution of the tourism industry to the GRP of Pavlodar region, \% 
The tourism industry is focused on providing a wide range of services, such as:

- hotel business (accommodation services);

- rest, entertainment;

- sports.
In these directions, Pavlodar region has a certain potential. The maximum volumes of provision of services related to tourism activities and the maximum rates of their growth occurred in 2017 and 2019. The growth rates of services in these periods were $114.1 \%$ and $107 \%$, respectively (Table 2, Figure 2).

Table 2 - Dynamics of the provision of services related to tourism activities in the context of cities, districts of Pavlodar region, a thousand tenge

\begin{tabular}{|l|c|c|c|c|c|}
\hline \multirow{2}{*}{\multicolumn{1}{|c|}{ City and district }} & \multicolumn{5}{c|}{ Year } \\
\cline { 2 - 6 } & 2015 & 2016 & 2017 & 2018 & 2019 \\
\hline Pavlodar region & 9592200 & 8668100 & 9886100 & 7989000 & 8544400 \\
\hline Pavlodar & 6323200 & 5007300 & 5598400 & 3168600 & 3845900 \\
\hline Aksu & 401200 & 406500 & 563300 & 625900 & 632200 \\
\hline Ekibastuz & 731800 & 956900 & 1203700 & 1093500 & 1217800 \\
\hline Aktogay district & 139200 & 225800 & 198200 & 209700 & 220900 \\
\hline Bayanaul district & 238000 & 341100 & 279100 & 329800 & 375800 \\
\hline Zhelezinka district & 81900 & 163500 & 216900 & 228700 & 269200 \\
\hline Irtyshsk district & 145600 & 176000 & 240000 & 195000 & 208000 \\
\hline Terenkol district & 153600 & 204800 & 218400 & 243400 & 275800 \\
\hline Akkuly district & 132600 & 149900 & 121200 & 135900 & 163500 \\
\hline Mayskiy district & 144300 & 171500 & 188700 & 203700 & 253800 \\
\hline Pavlodar district & 199400 & 321900 & 348100 & 389800 & 366800 \\
\hline Uspenskiy district & 149400 & 181500 & 211600 & 238200 & 234300 \\
\hline Sherbakty district & 169300 & 225900 & 220000 & 318800 & 285900 \\
\hline \multicolumn{2}{|c|}{ Note - In accordance with source [13] } & & & & \\
\hline
\end{tabular}

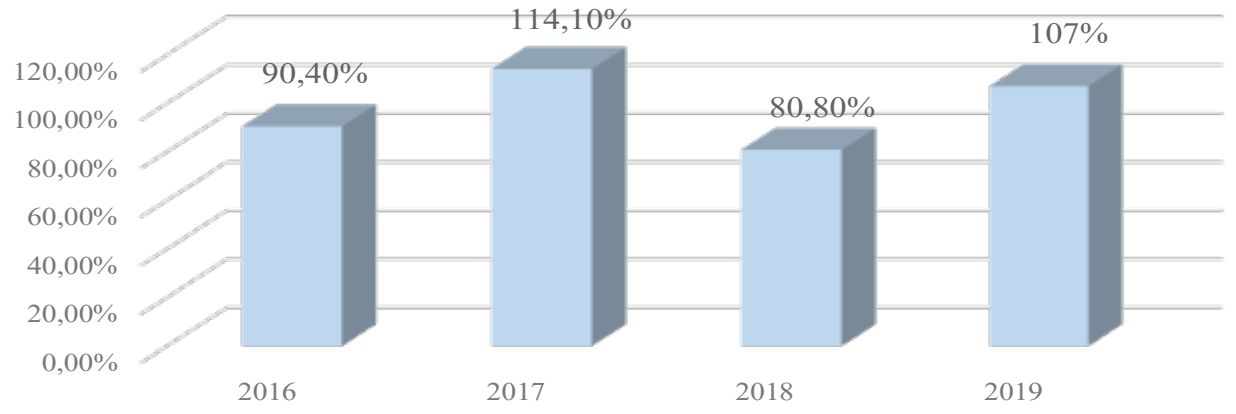

Note - In accordance with source [13]

Figure 2 - Dynamics of growth rates in the provision of services related to tourism activities, \%

The main range of services related to tourist activities falls on the cities of Pavlodar region (Pavlodar city, Ekibastuz city, Aksu city). The minimum volume of services falls on the regions of the region, rural areas.

All services related to tourism activities, in the context of enlarged types, are concentrated in two areas:

- accommodation services (hotel services);
- other services for organizing recreation.

The study of the dynamics of consolidated types of services related to tourism activities shows that there is a positive dynamics of accommodation services, while negative dynamics of services for the organization of recreation (Table 3). Nevertheless, from 2015 to 2019, in the structure of services related to tourism activities, recreation services prevailed (Figure 3). 
Table 3 - Dynamics of tourist services in the context of their enlarged types, a thousand tenge

\begin{tabular}{|l|c|c|c|c|c|}
\hline \multirow{2}{*}{ Index } & \multicolumn{5}{c|}{ Year } \\
\cline { 2 - 6 } & 2015 & 2016 & 2017 & 2018 & 2019 \\
\hline Accommodation services & 324833,4 & 1591832,4 & 1852259,7 & 2130571,5 & 3367502,4 \\
\hline Other leisure services & 9267366,60 & 7076267,60 & 8033840,30 & 5858428,50 & 5176897,60 \\
\hline Total & 9592200 & 8668100 & 9886100 & 7989000 & 8544400 \\
\hline \multicolumn{7}{|c|}{ Note - In accordance with sources [13 - 18]. } \\
\hline
\end{tabular}

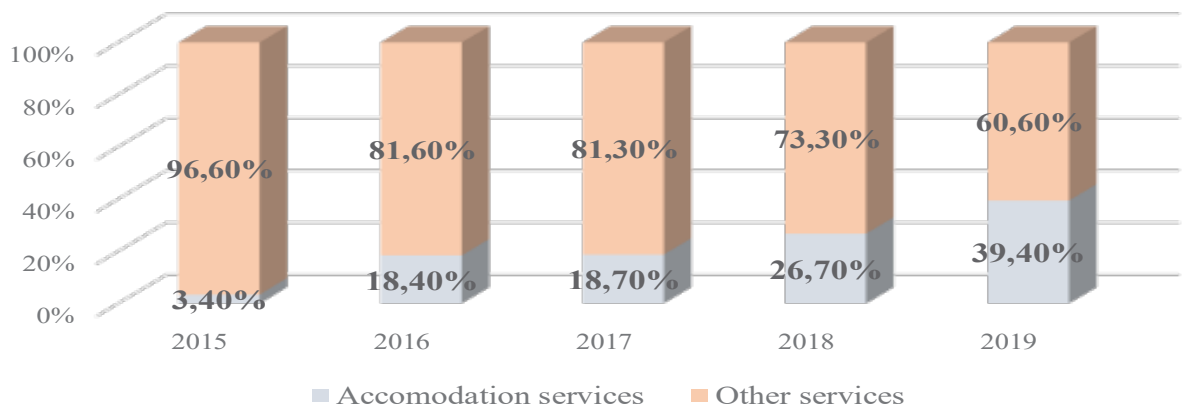

Note - In accordance with sources [13 - 18]

Figure 3 - Dynamics of the structure of services related to tourism activities in the context of their enlarged types, $\%$

As part of the growth dynamics of accommodation services, positive dynamics occurs in the following districts of the Pavlodar region:

- the city of Pavlodar;

- the cities of Aksu and Ekibastuz;

- Bayanaul district.
Good positive dynamics of accommodation services was typical for Bayanaul district. The growth rate of this type of service was:

$$
\begin{aligned}
& \text { - } 2017 \text { - 105,4\%; } \\
& \text { - } 2018 \text { - 111,8\%; } \\
& \text { - } 2019 \text { - 114\% (Figure 4). }
\end{aligned}
$$

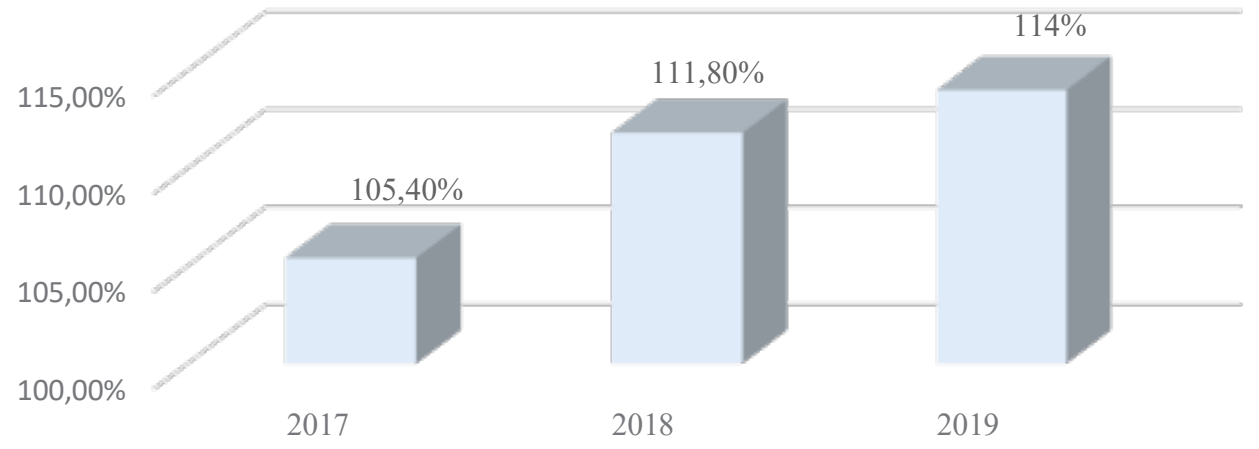

Note - In accordance with [14 - 18]

Figure 4 - Growth rate of accommodation services in Bayanaul district, \% 
At the regional level, the demand for services related to tourism activities is formed by two types of subjects of market relations:

- individuals (population);

- legal entities.
It should be noted that there is a decrease in demand for tourist services from individuals (Table 4).

Table 4 - Dynamics of services related to tourism activities, in the context of major consumers, a thousand tenge

\begin{tabular}{|l|c|c|c|c|c|}
\hline \multirow{2}{*}{ Index } & \multicolumn{5}{c|}{ Year } \\
\cline { 2 - 6 } & 2015 & 2016 & 2017 & 2018 & 2019 \\
\hline Individuals (population) & 3044400 & 1665100 & 2017800 & 1843100 & 1644900 \\
\hline Legal entities & 6547800 & 7003000 & 7868200 & 6145900 & 6899400 \\
\hline Total & 9592200 & 8668100 & 9886100 & 7989000 & 8544400 \\
\hline
\end{tabular}

Tourism as a branch of the economy, primarily engaged in organizing free time, can successfully exist under two conditions:

- free time of citizens;

- sufficient material resources, income of individuals.

Thus, the necessary prerequisites for the emergence of massive demand for tourism and maintaining it at a high level are an increase in free time and an increase in the well-being of society, citizens of Pavlodar region and the Republic of
Kazakhstan as a whole. The need for rest belongs to the upper level of the pyramid of human needs [19].

In view of the above, it should be assumed that as real services directly related to tourism, services should be considered for which demand is from individuals. The latter allows a comparable assessment of the nominal and real contribution of the tourism industry to the development of the economy of the Pavlodar region (Table 5, Figure $5)$.

Table 5 - Dynamics of the assessment of the nominal and real contribution of the tourism industry to GRP

\begin{tabular}{|l|c|c|c|c|c|}
\hline \multicolumn{1}{|c|}{ Index } & \multicolumn{5}{c|}{ Year } \\
\cline { 2 - 6 } & 2015 & 2016 & 2017 & 2018 & 2019 \\
\hline Gross regional product of Pavlodar region, a billion tenge & 1736,2 & 1975,5 & 2369,3 & 2746,7 & 2805,9 \\
\hline $\begin{array}{l}\text { Nominal tourism services (full range of services directly } \\
\text { and indirectly related to tourism), a billion tenge }\end{array}$ & 9,6 & 8,7 & 9,9 & 7,9 & 8,5 \\
\hline $\begin{array}{l}\text { Real tourist services (services directly related to tourist ac- } \\
\text { tivities), a billion tenge }\end{array}$ & 3,04 & 1,7 & 2,02 & 1,84 & 1,64 \\
\hline Nominal contribution of the tourism industry to GRP, \% & 0,55 & 0,44 & 0,42 & 0,29 & 0,30 \\
\hline The real contribution of the tourism industry to GRP, \% & 0,18 & 0,09 & 0,09 & 0,07 & 0,06 \\
\hline \multicolumn{1}{|c|}{ Note - In accordance with sources [12, 13]. } & & & & & \\
\hline
\end{tabular}

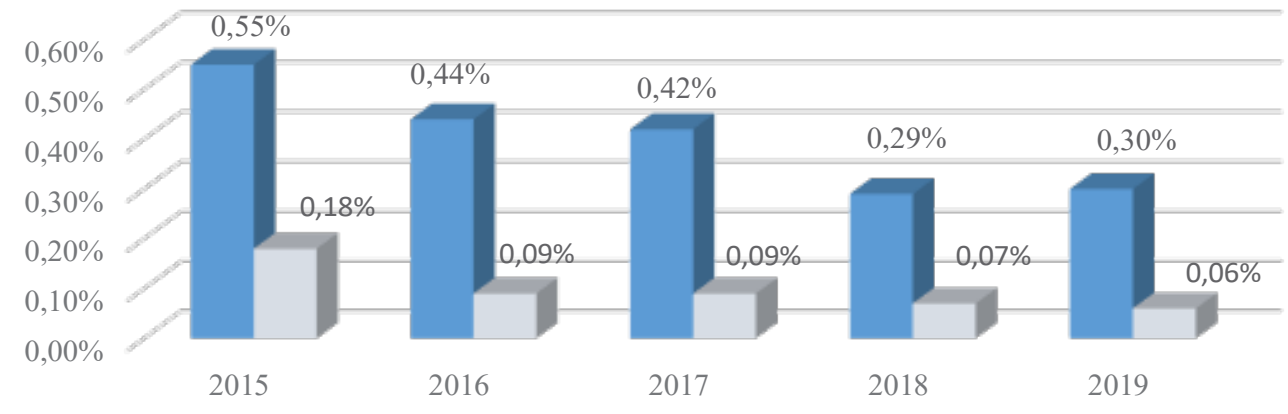

nominal share of the tourism industry in GRP,\% $\quad$ Real share of the tourism industry in GRP,\%

Note - In accordance with sources $[12,13]$

Figure 5 - Comparable assessment of the dynamics of the nominal and real contribution of the tourism industry to the development of the economy of the Pavlodar region, \% 
In general, at the present stage, the contribution of the tourism industry to the development of the region, both from a nominal and from a real point of view, remains at a very low level.

One of the resulting foundations of the economic results of the functioning of the tourism industry of Pavlodar region are: tourism;

- employment of the population in the field of sector;

- Average salary of workers in the tourism

- labor productivity in the tourism sector.

The employment of the population in the tourism sector is cyclical (Figure 6).

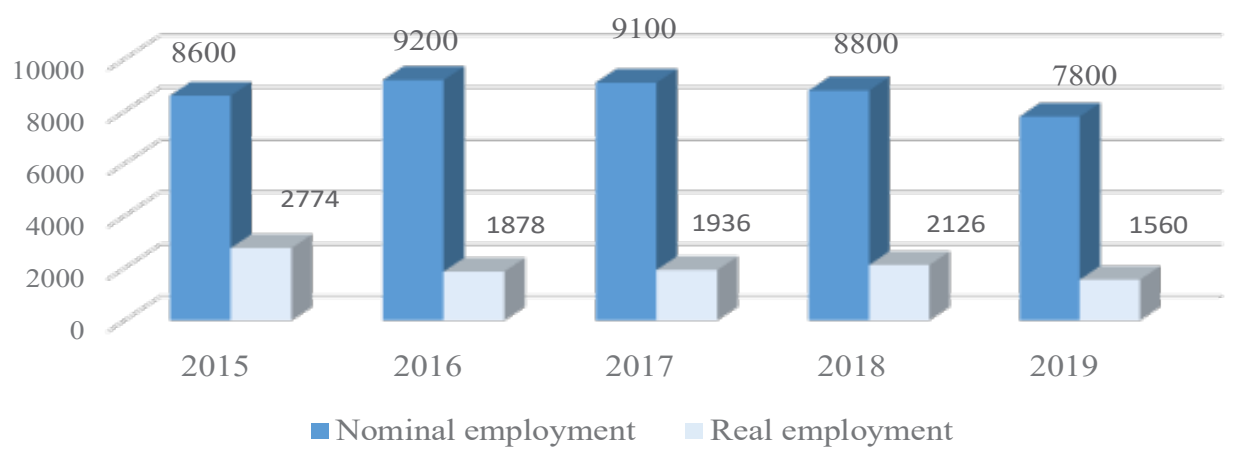

Note - In accordance with source [20]

Figure 6 - Dynamics of employment in the tourism industry

The maximum peak of employment in the tourism sector was in 2016-2017. During these periods, 9,200 and 9,100 people were employed in the tourism sector, respectively.
In the tourism industry, there was an increase in average wages, which over the past five years increased from 67.2 thousand tenge to 103.2 thousand tenge (Figure 7).

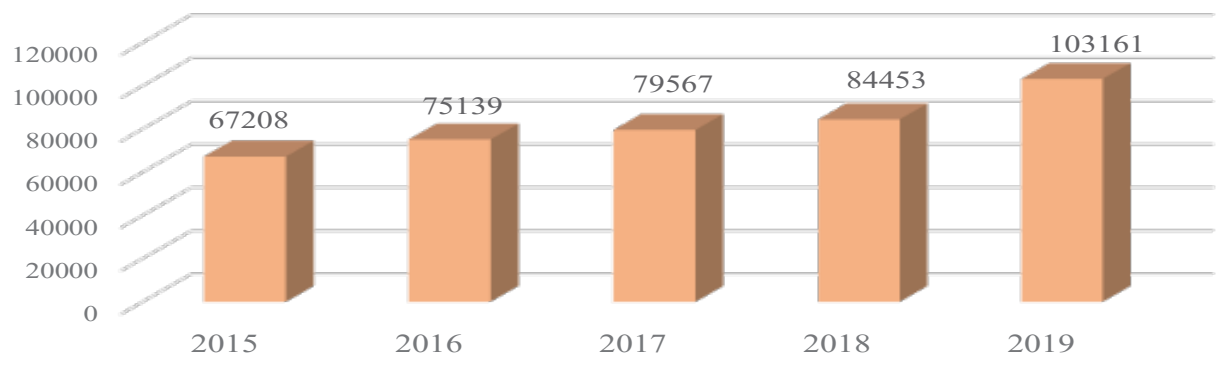

Note - In accordance with source [20]

Figure 7 - Dynamics of the average salary in the tourism industry, tenge

By comparing the dynamics of employment and the nominal volumes of production of services related to tourism activities, it is possible to determine the dynamics of labor productivity in the tourism industry (Figure 8).

Comparing the dynamics of labor productivity in the tourism industry and the dynamics of employment in the tourism industry, it is clear that, with a certain degree of probability, there is an intensification of labor processes. Nevertheless, the value of productivity remains at a very low level.

The initial infrastructural organizational and economic foundations for the functioning of the tourism industry are:

- organizations providing a range of services related to tourism activities;

- production facilities of the hotel business;

- availability of fixed capital (fixed assets).

The dynamics of organizations providing services related to tourism activities is cyclical. The total number of organizations providing services related to tourism activities from 2015 to 2019 decreased from 193 units to 137 units (Figure 9). The bulk of the services provided falls on small businesses (Figure 10). 


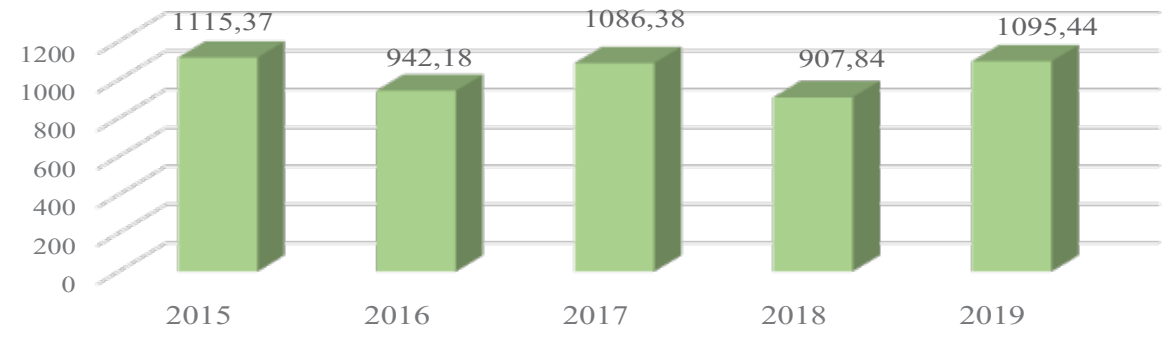

Note - In accordance with source [20]

Figure 8 - Dynamics of labor productivity in the sphere of services related to tourism activities, a thousand tenge/person

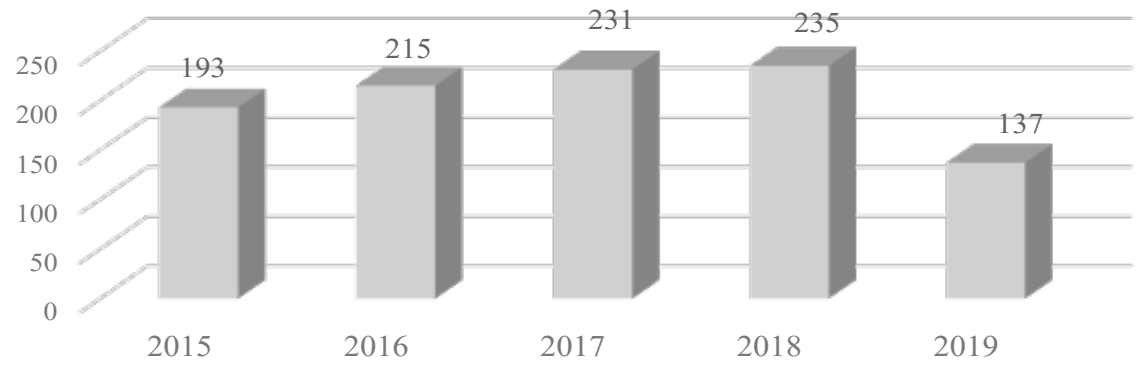

Note - In accordance with source [13]

Figure 9 - Dynamics of organizations providing services related to tourism activities, units

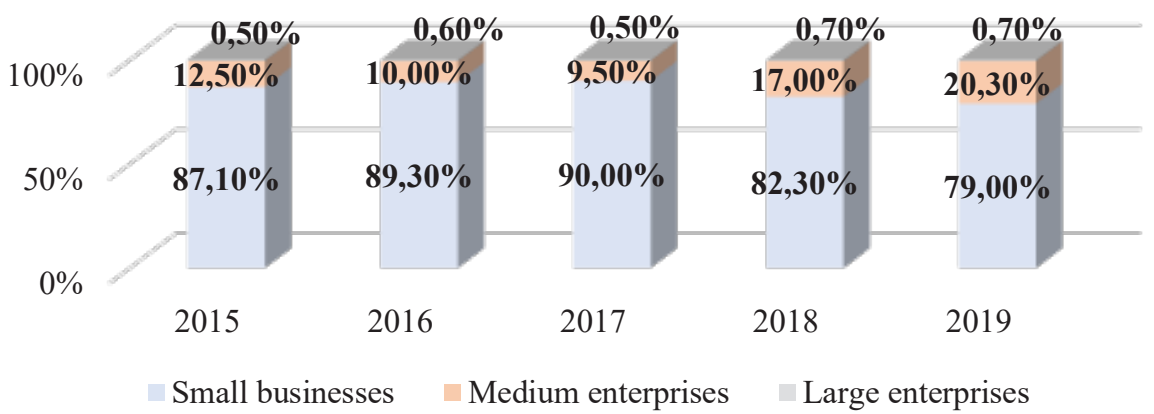

Note - In accordance with source [13]

Figure 10 - Dynamics of the structure of tourism services in the context of enterprises by size, $\%$

The following should be considered as the leading production facilities in the tourism sector of Pavlodar region:

- the number of accommodation rooms in hotel complexes;

- the potential number of guests for one-time accommodation.

The dynamics of the number of guests for one-time accommodation is presented in table 6 .

The maximum production capacity of tourist activities for the simultaneous accommodation of guests falls on the city of Pavlodar and the Bayanaul region.

In Pavlodar region, there is a positive trend in the level of capitalization of the tourism industry. As of 2019, the value of fixed assets in the tourism sector is 24,9 billion tenge. At the same time, there are growing trends in the wear of fixed assets. As of 2019 , the degree of depreciation of fixed assets in the tourism industry was $46.2 \%$ (Table 7 ).

The level of efficiency of fixed assets in the tourism industry can be characterized by the rate of return on assets (Figure 11). 
Table 6 - Dynamics of production capacities of tourism activities for one-time accommodation of guests, number of people

\begin{tabular}{|c|c|c|c|c|c|}
\hline \multirow[t]{2}{*}{ City and district } & \multicolumn{5}{|c|}{ Year } \\
\hline & 2015 & 2016 & 2017 & 2018 & 2019 \\
\hline Pavlodar region & 4648 & 5800 & 5620 & 5584 & 6116 \\
\hline Pavlodar & 1708 & 1996 & 1976 & 1718 & - \\
\hline Aksu & 338 & 362 & 330 & 330 & - \\
\hline Ekibastuz & 450 & 488 & 344 & 344 & 348 \\
\hline Aktogay district & 0 & 6 & 6 & 14 & 14 \\
\hline Bayanayl district & 1676 & 2494 & 2520 & - & 2964 \\
\hline Zhelezinska district & 6 & 8 & 8 & - & 6 \\
\hline Irtyshk district & 24 & 44 & 44 & 44 & 68 \\
\hline Terenkol district & - & 0 & 0 & 14 & 44 \\
\hline Akkuly district & - & 10 & 0 & 0 & - \\
\hline Maiskiy district & - & 2 & 2 & 0 & - \\
\hline Pavlodar district & 254 & 198 & 198 & 198 & - \\
\hline Sherbakty district & 192 & 192 & 192 & 202 & 210 \\
\hline Note - In accordance with sources $[14-18]$ & & & & & \\
\hline
\end{tabular}

Table 7 - Dynamics of the state of fixed capital of the tourism industry

\begin{tabular}{|l|c|c|c|c|c|}
\hline \multicolumn{1}{|c|}{ Index } & \multicolumn{5}{c|}{ Year } \\
\cline { 2 - 6 } & 2015 & 2016 & 2017 & 2018 & 2019 \\
\hline Initial cost of fixed capital, million tenge & 21929,7 & 22351,4 & 22513,3 & 21636,0 & 24968,4 \\
\hline Balance sheet value of fixed capital, million tenge & 12750,0 & 13001,5 & 12343,7 & 11157,5 & 13428,9 \\
\hline Depreciation rate of fixed assets, \% & 41,9 & 41,8 & 45,2 & 48,4 & 46,2 \\
\hline Note - In accordance with source [21].
\end{tabular}

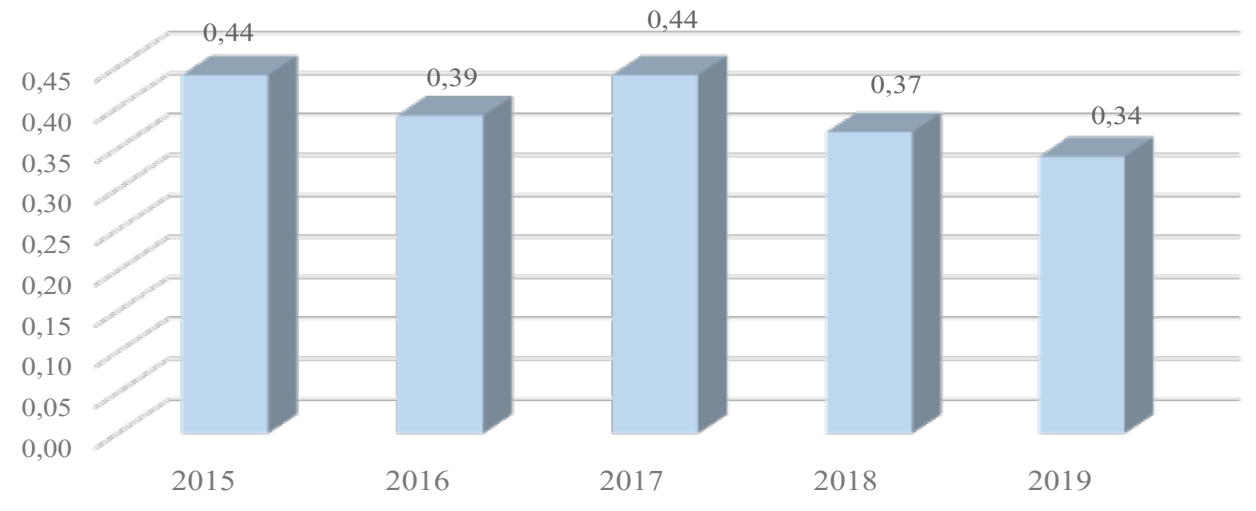

Note - In accordance with sources [21]

Figure 11 - Rate of return on assets in the tourism industry

Research and analysis of general economic trends in the functioning of the tourism industry in Pavlodar region makes it possible to carry out an integrated analytical assessment of medium-term investments based on the following assessments:

- forecasting the mid-term dynamics of the contribution of the tourism industry to the GRP of Pavlodar region;
- forecasting investments in the development of the tourism industry within the framework of state support;

- forecasting investments in the development of the tourism industry within the framework of state support and attracting private investment;

- forecasting employment and labor productivity in the tourism industry; 
- forecasting the resulting indicators of the development of the tourism industry in Pavlodar region.
Forecasts of the gross regional product and the share of the tourism industry in the regional economy make it possible to predict the total volume of tourism services until 2025 (Table 8).

Table 8 - Forecasting the medium-term dynamics of the contribution of the tourism industry to the GRP of Pavlodar region

\begin{tabular}{|l|c|c|c|c|c|c|}
\hline \multirow{2}{*}{ Index } & \multicolumn{5}{c|}{ Year } \\
\cline { 2 - 7 } & 2020 & 2021 & 2022 & 2023 & 2024 & 2025 \\
\hline $\begin{array}{l}\text { Gross regional product (GRP) of Pav- } \\
\text { lodar region, a billion tenge (forecast) }\end{array}$ & 2867,63 & 2982,33 & 3039,69 & 3191,10 & 3282,86 & 3510,21 \\
\hline $\begin{array}{l}\text { GRP growth rate of Pavlodar region, } \\
\% \text { (forecast) }\end{array}$ & 102,2 & 104 & 106 & 107 & 108 & 110 \\
\hline $\begin{array}{l}\text { Real share of the tourism industry in } \\
\text { GRP (plan), \% }\end{array}$ & 0,06 & 0,16 & 0,26 & 0,36 & 0,46 & 0,56 \\
\hline Tourist services, a billion tenge (plan) & 1,72 & 4,77 & 7,90 & 11,49 & 15,10 & 19,66 \\
\hline \multicolumn{7}{|l|}{ Note - Compiled by the authors. } \\
\hline
\end{tabular}

Comparison of the forecast of the volume of tourist services with the forecast of the growth of capital productivity allows to determine the forecast of investments in fixed assets of the tourism industry, as well as the required amount of minimum investment in human resources and administration processes (Table 9).

Table 9 - Forecasting investments in the development of the tourism industry within the framework of state support

\begin{tabular}{|c|c|c|c|c|c|c|}
\hline \multirow{2}{*}{ Index } & \multicolumn{6}{|c|}{ Year } \\
\hline & 2020 & 2021 & 2022 & 2023 & 2024 & 2025 \\
\hline Tourist services, a billion tenge (plan) & 1,72 & 4,77 & 7,90 & 11,49 & 15,10 & 19,66 \\
\hline Return on assets, coeff. & 0,34 & 0,38 & 0,42 & 0,46 & 0,5 & 0,54 \\
\hline $\begin{array}{l}\text { Dynamics of investments in fixed as- } \\
\text { sets, a thousand tenge }\end{array}$ & - & 1812600 & 3318000 & 5285400 & 7550000 & 10616400 \\
\hline $\begin{array}{l}\text { Investments in HR and process admin- } \\
\text { istration, a thousand tenge }(1 \%)\end{array}$ & - & 9063,00 & 16590,00 & 26427,00 & 37750,00 & 53082,00 \\
\hline Total investments, a thousand tenge & - & 1821663 & 3334590 & 5311827 & 7587750 & 10669482 \\
\hline
\end{tabular}

Calculations show that the total need for investments for the development of the tourism industry in Pavlodar region is about 28.7 billion tenge, calculated for a strategic period of 5 years. This investment can be financed from all potential possible sources (government budget, private investment, foreign investment, corporations).

Investments planned and implemented in practice in the development of the tourism industry of Pavlodar region will intensify the trends of its development and create new quality conditions for the economic growth of the region.

The presented investment planning methodology is of great importance for the scientific substantiation of the ways of development of the tourism industry in all regions of the Republic of Kazakhstan. Investments, the volume of tourist services, should develop not only from a quantitative standpoint, but also have a qualitative impact on the region's economy (growth of the gross regional product, growth in labor productivity and employment).

\section{Conclusion}

Research and analysis of general economic trends in the functioning of the tourism industry in Pavlodar region shows that tourism activities and the industry as a whole are at the initial stage of formation and development, despite a rather long period of formation and evolution of market relations in the Republic of Kazakhstan. The tourism industry operates cyclically, which indicates the systemic problems of its development and intensification. Despite this, the use of targeted software tools for reforming the tourism industry allows in the strategic period to significantly 
improve the quality results of its functioning. By 2025, due to targeted investment attraction in the region's tourism industry, its share in the economy may grow to $0.56 \%$, and the total volume of tourism services will increase 11.4 times. As a consequence, there will be a gradual diversification of the regional economy from the construction industry towards services with high added value.

\section{References}

1 Uakbaev Sh.U. Tourism as a factor of regional and interregional development. URL: https://articlekz. com/article/19846 (date accessed: 31.01.2021).

2 Perelygina M. Cultural distance: visa accessibility approach // Regional tourism: experience, problems, prospects. Collection of scientific articles. Issue 7. (Materials of the V International Scientific Conference «Regional Tourism: Experience, Problems, Prospects», September 27, 2018, Izhevsk). - Izhevsk: Institute for Computer Research, 2018 . - 184 p.

3 Novikova N.G., Lebedev K.A., Lebedeva O.E. regional tourism as a factor of socioeconomic development of the economy // Bulletin of SUSU. Series «Economics and Management».- 2016. - T. 10, No 2.p. $15-21$.

4 Doina D.F. Innovative regional cluster, model of tourism development // Procedia economics and finance, 2015 - Volume 23, - P. 744-749. URL: https://doi. org/10.1016/S2212-5671(15)00501-8 (date accessed: 31.01.2021).

5 Calero C., Turner L.W. Regional economic development and tourism: A literature review to highlight future directions for regional tourism research // Tourism Economics. - 2019. - Volume: 26 issue: 1. - P. 3-26. URL: https://doi.org/10.1177/1354816619881244 (date accessed: 31.01.2021).

6 Cro S., Martins A.M. Foreign Direct Investment in the tourism sector: The case of France // Tourism Management Perspectives. - 2020. - Volume 33, P. 1118. URL: https://doi.org/10.1016/j.tmp.2019.100614 (date accessed: 19.02.2021).

7 Ilie G. Foreign direct investment in tourism sector // Knowledge Horizons - Economics. - 2015. - Volume 7, P. 9-13, URL: http://orizonturi.ucdc.ro/ arhiva/khe-vol7-nr3-2015/Georgeta_Ilie.pdf (date accessed: 19.02.2021).

8 Bezic H., Radic M.N. Tourism foreign direct investment led tourism gross value added: a cointegration and causality analysis of Croatian tourism // Economic Research-Ekonomska Istraživanja. - 2017. - voL. 30, no. 1. - P. 1443-1460, URL: https://doi.org /10.1080/1331677X.2017.1340173 (date accessed: 19.02.2021).

9 Ohlan R. The relationship between tourism, financial development and economic growth in India // Future Business Journal. - 2017. - Volume 3, Issue 1. - P. 9 - 22, URL: https://doi.org/10.1016/j.fbj.2017.01.003 (date accessed: 21.02.2021).

10 Suhel S., Bashir A. The role of tourism toward economic growth in the local economy // Economic Journal of Emerging Markets. -2018.- N 10 (1). - P. 32-
39. URL: https://journal.uii.ac.id/JEP/article/view/7714 (date accessed: 21.02.2021).

11 Tulbayeva A, Abdikarimova M., Ganitaev M., Imangulova T., Pestova A. Optimization problems distribution of investments for the implementation strategy of domestic tourism in Kazakhstan // Revista Espacios. - 2017. - Vol. 38 (No 47). P. 37. URL: http:// www.revistaespacios.com/a17v38n47/a17v38n47p37. pdf (date accessed: 21.02.2021).

12 Pavlodar region in 2019 // Statistical collection. $-2020 .-233 \mathrm{p}$.

13 Services and culture in the Pavlodar region // Statistical collection. -2020 . $-74 \mathrm{p}$.

14 On the activities of placements in Pavlodar region // Tourism statistics. $-2015 .-13 \mathrm{p}$.

15 On the activities of placements in Pavlodar region // Tourism statistics. $-2016 .-14 \mathrm{p}$.

16 On the activities of placements in Pavlodar region // Tourism statistics. -2017 . $-16 \mathrm{p}$.

17 On the activities of placements in Pavlodar region // Tourism statistics. - 2018. $-16 \mathrm{p}$.

18 On the activities of placements in Pavlodar region // Tourism statistics. $-2019 .-17$ p.

19 Kvartalnov V.A. Tourism. Marketing of the market of consumers of tourist services. URL: https:// tourlib.net/books_tourism/kvartalnov_tourism $14 . \mathrm{htm}$ (date accessed: 31.01.2021).

20 Employment and wages in the Pavlodar region // Statistical collection. -2020 . $-140 \mathrm{p}$.

21 Fixed assets of the Pavlodar region // Statistical collection. $-2020 .-65 \mathrm{p}$. 


\section{Information about the authors}

Titkov A.A. - Toraighyrov University, 140000, Republic of Kazakhstan, Pavlodar city, Lomova street 64, professor of the Department of Economics. E-mail: Alexey-pvl@mail.ru; https://orcid.org/0000-0001-9126-2337

Ibraimova S.Zh. - corresponding author, Kazakh University of Technology and Business, 010000, Republic of Kazakhstan, Nur-Sultan city, st. Kayim Mukhamedkhanova, building 37 A, Professor of the Department of Economics, Accounting and Auditing. E-mail: saule_ibraimova_kz@mail.ru; https://orcid.org/0000-0001-6506-2446

Begentayev M.M. - Toraighyrov University, 140000, Republic of Kazakhstan, Pavlodar city, Lomova street 64, professor of the Department of Economics. E-mail: begentaev_meiram@mail.ru; https://orcid.org/0000-0001-96884370

Kunyazova S.K. - Toraighyrov University, 140000, Republic of Kazakhstan, Pavlodar city, Lomova street 64 , professor of the Department of Economics. E-mail: kunjazovas@mail.ru; https://orcid.org/0000-0002-5538-5839

\section{Авторлар туралы мәліметтер}

Титков Алексей Анатольевич - Торайғыров университеті, 140000, Қазақстан Республикасы, Павлодар қаласы, Ломова көшесі 64, экономика кафедрасының профессоры. E-mail: Alexey-pvl@mail.ru; https://orcid. org/0000-0001-9126-2337

Ибраимова Сәуле Жұмағалиқыз - хат-хабаршы авторы, Қазақ Технологиялар және Бизнес Университеті, 010000, Қазақстан Республикасы, Нұр-Сұлтан қаласы, көш. Қайым Мұхамедханова, 37 А ғимарат, экономика, есеп және аудит кафедрасының профессоры. E-mail: saule_ibraimova_kz@mail.ru; https:// orcid.org/0000-0001-6506-2446

Бегентаев Мейрам Мұхаметрахимұлы - Торайғыров университеті, 140000, Қазақстан Республикасы, Павлодар қ., Ломова көшесі 64, экономика кафедрасының профессоры. E-mail: begentaev_meiram@mail.ru; https://orcid.org/0000-0001-9688-4370

Кунязова Сәуле Қайырбекқызы - Торайғыров университеті, 140000, Қазақстан Республикасы, Павлодар қаласы, Ломова көшесі 64, экономика кафедрасының профессоры. E-mail: kunjazovas@mail.ru; https://orcid. org/0000-0002-5538-5839 